\title{
EU-China Relations and Market Economy Status: EU foreign policy in the technical trap
}

\author{
Frank GAENSSMANTEL
}

In September 2011 an old issue returned to the fore of relations between China and the European Union (EU): the question of China's market economy status (MES). Chinese State Premier Wen Jiabao, in his opening speech at the World Economic Forum in Dalian, China, confirmed China's willingness to increase investment in Europe in support of the embattled euro, adding that it would be a sign of friendship if the EU could recognise China as a market economy and expressing his hope for progress on the matter during the next EU-China summit. ${ }^{1}$ These remarks followed shortly on reports about Italian efforts to convince Chinese government funds to purchase Italian debt, in an attempt to stem the tide of rising interest rates requested on Italian government bonds. ${ }^{2}$ Italy has been known as one of the EU member states with more protectionist reflexes when commercial relations with China are concerned, and the question arises of whether Wen's display of optimism on MES is in any way related to China's new leverage with Italy.

This points to a more general question: how to explain the EU's long and persistent refusal to grant MES to China? China has been asking the EU to recognise it formally as a market economy since 2002, and the EU has consistently refused recognition, despite repeated affirmations of various member states and EU institutions to grant MES to China. The official rhetoric of the EU has been that China does not fulfil the EU's technical criteria for recognising a country as a market economy, as defined in relevant Council Regulations. ${ }^{3}$ However, alternative explanations have pointed to deep divisions within the Council of Ministers between member states with more protectionist preferences and free-traders as main cause behind non-recognition. ${ }^{4}$

This article will first explore the significance of MES for China, then trace the evolution of the issue in China-EU relations, and offer conclusions on why the EU has continuously turned down China's request on the issue. I will argue that, rather than unfulfilled technical criteria or the simple fact of diverging interests of member states, it is the decision-making structure in Brussels that does not allow for the EU to go beyond the technical aspects and overcome its internal divisions. Although from

1. W. WANG, China Will Help Europe: Wen, in: Global Times, 15.09.2011. See also Foreign and Commonwealth Office (UK), China and the Eurozone - September 2011, 21.09.2011, available at: http://www.ukti.gov.uk/export/howwehelp/overseasbusinessrisk/item/195861.html (consulted 28.09.2011).

2. G. DINMORE, Italy turns to China for help in debt crisis, in: Financial Times, 12.09.2011.

3. The criteria had been mentioned for the first time in Council Regulation (EC) No 905/98 of 27 April 1998, in: Official Journal (hereafter: JO), L128, 30.04.1998, and have been reaffirmed most recently in Council Regulation (EC) No 1225/2009 of 30 November 2009, JO, L343, 22.12.2009.

4. For example J. FOX, F. GODEMENT, A Power Audit of EU-China Relations. Policy Report, European Council on Foreign Relations, London, 2009, p.35. 
the perspective of certain member states this may be precisely the desired outcome, for the EU as a whole this is a serious impediment in designing and implementing a common foreign policy. ${ }^{5}$

\section{The Commercial Significance of Market Economy Status for China}

The market economy label has consequences in the context of anti-dumping measures under the rules of the World Trade Organisation (WTO), of which both the EU and China are members. ${ }^{6}$ According to the WTO's "Agreement on Implementation of Article VI of GATT 1994", or simply the Anti-Dumping Agreement (ADA), "dumping" means to be selling a product in an export market below its "normal value [...] in the ordinary course of trade". 7 Therefore, a key element in determining whether or not dumping is occurring is the careful comparison between export price and "normal value", and it is in the definition of the "normal value" that MES becomes significant.

Elaborating on art.VI of GATT 1994, the ADA stipulates that usually the "normal price" for comparison should be the domestic price of the concerned product in the exporting country. ${ }^{8}$ When there are no domestic sales, or when their low volume or any "particular market situation" in the exporting country do not allow for a "proper comparison" of prices along these lines, other rules are available to determine the normal price, namely using "a comparable price of the like product when exported to an appropriate third country" or "the cost of production in the country of origin". ${ }^{9}$ In addition, however, the ADA also re-affirms the provisions on anti-dumping in Annex I to GATT 1994, where it is acknowledged that "in the case of imports from a country which has a complete or substantially complete monopoly of its trade and where all domestic prices are fixed by the State, special difficulties may exist in determining price comparability [...], and in such cases importing contracting parties

5. The research for this article is based on interviews with policy makers and policy consultants in China and Europe, conducted between summer 2006 and autumn 2008. Altogether there are 19 relevant interviews on the Chinese side and 39 on the EU side. All interviewees were promised anonymity therefore references are coded, including only indication on which policy process the interviewee is part of (China or EU) and on when the interview was held (quarter of a year).

6. The EU is among the founding members of the World Trade Organisation (WTO) and all its member states have been GATT signatories (prior to the founding of the WTO in 1995) or WTO members before joining the EU. China acceded to the WTO on 11 December 2001. See "Members and Observers". Understanding the WTO: The Organization (website), World Trade Organisation, last accessed 0410.2011, http://wto.org/english/thewto_e/whatis_e/tif_e/org6_e.htm.

7. Agreement on Implementation of Article VI of GATT 1994, art.2(1).

8. GATT 1947 art.VI (1a) and Agreement on Implementation of Article VI of GATT 1994, art.2(1).

9. Agreement on Implementation of Article VI of GATT 1994 art.2(2). 
may find it necessary to take into account the possibility that a strict comparison with domestic prices in such a country may not always be appropriate". ${ }^{10}$

In the case of trade relations with countries in transition from a planned to a market-based economic system, instead of reverting on a case-by-case basis to the ADA rules on particular market situations, importing countries have usually preferred to benefit from the vague language of the GATT annex and the "significant discretion in the calculation of normal value of products exported from non-market economies". ${ }^{11}$ In practice, this means that transition economies are typically designated as non-market economies, often in defiance of the strict language on monopoly and state control in the GATT provision, and subjected to the so-called "surrogate" or "analogue" country approach, under which prices and costs in a non-market economy are disregarded completely, "on the ground that they are unreliable because they are not set by market forces", and substituted with data from a third country that is recognised as a market economy. As there are no specific GATT rules on how to select the substitute country, it is hard to preclude a protectionist bias in the choice, and in fact the approach has been criticised as generating frequent and high antidumping duties. ${ }^{12}$

Against this background it is understandable that Chinese authorities expect a certain economic benefit for their exporters from being granted MES by the EU as their number one trading partner. As long as China is treated as a non-market economy, EU authorities enjoy a significant degree of freedom to revert to anti-dumping duties when this is deemed necessary to protect EU commercial interests. By contrast, recognition as a market economy can be expected to lead to less and lower antidumping duties on the part of the EU against Chinese exporters.

\section{The Importance of Status}

Aside from the commercial implications, for China MES is also a question of status in the true sense of the word. Observers have pointed out that "Beijing [...] attaches political significance to the status and sees it as another milestone in its efforts to be considered on an equal footing with the largest western industrialised powers", ${ }^{13}$ and that, "symbolically, MES would herald China's arrival as a major industrialised world

10. Agreement on Implementation of Article VI of GATT 1994, art.2(7); Annex I to GATT 1994, second Supplementary Provision to Art.VI, par.1.

11. WTO, Technical Information about Anti-Dumping, Anti-Dumping (website), last accessed 04.10.2011, http://www.wto.org/english/tratop_e/adp_e/adp_info_e.htm.

12. See E. VERMULST, The WTO Anti-Dumping Agreement $-A$ Commentary, Oxford University Press, Oxford, 2005, pp.44-45.

13. J. LAU, R. MINDER, Recognise China as a market economy, says UK, in: Financial Times, 05.07.2005. 
trade player". ${ }^{14}$ In 2004 Stephen Green, at that time head of the Asia Programme at Chatham House, noted that MES was "a matter of national pride", and that recognition would be, "like the 2008 Olympic Games, a stamp of international approval". ${ }^{15}$

Statements by Chinese officials confirm that MES matters per se as a symbol of China's international status. Two major interpretations can be distinguished. On the one hand, conferral of the market economy label is seen as an expression of approval for China's reform efforts. ${ }^{16}$ The spokesman of the Chinese Ministry of Foreign Affairs (MFA), Liu Jianchao, for example declared in July 2005 that the EU's recognition of "China's full market economy status" would mean acknowledging "China's positive efforts made in the establishment of [a] socialist market economy system". ${ }^{17}$ On the other hand, there is the view that granting MES would show respect for China as an equal partner. State Premier Wen Jiabao, for instance, stated at the EU-China summit in Helsinki in September 2006 that granting MES would "reflect mutual respect and equality". ${ }^{18}$ A similar view can be discerned in the comments of a Chinese diplomat in Brussels who said that non-recognition amounted to unfair treatment, in particular when compared with Russia which was granted MES in November 2002. ${ }^{19}$

It should be emphasised that the symbolic dimension, i.e. the emphasis on MES as a mark of progress and respect, is more than simple rhetoric. Questions of China's international status and the related symbols have indeed been of great importance for Chinese foreign-policy makers, as a reaction to what has been perceived as a "humiliation" at the hands of foreign imperial powers during the $19^{\text {th }}$ and $20^{\text {th }}$ century. ${ }^{20}$ As a result,

"[a]lmost all powerful Chinese political leaders from the early twentieth century through today have shared a deep bitterness at this humiliation and have determined to restore China's pride and prestige, as well as its rightful place in the world". ${ }^{21}$

14. A. CHANDA, EU-China summit starts in Beijing, amid trade tensions and long-simmering disagreements, in: Worlds Markets Research Centre, World Markets Analysis, 05.09.2005.

15. S. GREEN, China's Quest for Market Economy Status. Asia Programme Briefing Notes, Royal Institute of International Affairs, London, May 2004, p.2.

16. Interview China 7, Shanghai Q3 2007.

17. China calls for EU recognition of full market economy status, in: BBC Monitoring Europe - Political, quoting Xinhua News Agency, 14.07.2005.

18. D. IBISON, Brussels refuses to yield over market economy status for China, in: Financial Times, 11.09.2006.

19. Interview China 11, Brussels Q1 2008.

20. J.W. GARVER, Foreign Relations of the People's Republic of China, Prentice Hall, Englewood Cliffs, 1993, p.4.

21. S. ZHAO, China's Pragmatic Nationalism: Is It Manageable?, in: The Washington Quarterly, 1(2005), pp.131-144, here: p.133. 


\section{Market Economy Status in China-EU relations during the 1990s}

Even before China's accession to the WTO in 2001, MES was already an issue on the commercial agenda of China-EU relations. In fact, throughout the 1990s the EU did not distinguish between WTO members and non-members in its anti-dumping practice. Council Regulation (EC) No. 3283/94 of 22 December 1994, ${ }^{22}$ the first regulation setting out rules on anti-dumping after the termination of the Uruguay Round, contained special provisions for non-market economies in art.2(7) but no specification concerning WTO membership. In the past GATT signatories had indeed been on the list of non-market economies, like for example Hungary, Poland and Romania in the $1980 \mathrm{~s} .{ }^{23}$

A few years before China's accession to the WTO, the country was promoted by the EU from the basic non-market economy regime towards a treatment more in line with the regular WTO rules that apply to market economies. For non-market economies, the EU's initial assumption had been that "all the means of production and natural resources belong to one entity, the State", therefore considered the "single producer", meaning that a "single rate" had to be applied "to avoid circumvention of the duties, that is the channelling of exports through the exporter with the lowest duty rate". ${ }^{24}$ As a result, the analogue country approach, as established in the basic regulations on anti-dumping passed in 1994 and 1996, ${ }^{25}$ was applied collectively to all producers of the exporting country.

However, according to the ADA, the magnitude of dumping and the anti-dumping duty should in principle be determined individually for every exporting firm. ${ }^{26}$ In the mid-1990s already the EU started to introduce a slightly more flexible approach towards non-market economies in general, by which dumping and the related duties could be determined individually in "exceptional cases where a company can show that it operates independently from the state". ${ }^{27}$ China, however, was selected for an exceptionally favourable treatment in April 1998, when it was removed, along with Russia, from the list of non-market economies to which anti-dumping duties were applied collectively. Instead a system was instituted by which individual firms could demonstrate "that market economy conditions prevail" based on specific market

22. JO, L349, 31.12.1994.

23. B.V. HINDLEY, The Regulation of Imports from Transition Economies by the European Union, in: P.D. EHRENHAFT et al., Policies on Imports from Economies in Transition: Two Case Studies, The World Bank, Washington DC, 1997, pp.43-65, here: pp.44-45.

24. EUROPEAN COMMISSION, On the Treatment of Former Non-Market Economies in Anti-Dumping Proceedings (COM (1997) 677 final), p.3.

25. See art.2(7) in both Council Regulation (EC) No. 3283/94 of 22 December 1994, in: JO, L349, 31.12.1994; Council Regulation (EC) No 384/96 of 22 December 1995, in: JO, L56, 06.03.1996.

26. According to art. 6(10) of the Agreement on Implementation of Article VI of GATT 1994 individual dumping margins must be determined for every concerned exporter or producer; these margins constitute the upper limit for anti-dumping duties according to art.9(3); in case exporters or producers are too numerous art.6(10) and 9(4) provide how to determine dumping margins based on samples and how to determine anti-dumping duties for individual firms based on this method.

27. EUROPEAN COMMISSION, On the Treatment ..., op.cit., p.3. 
economy criteria. ${ }^{28}$ If a producer passed the test, the same anti-dumping rules would be applied as for producers in market economy countries, if not the collective analogue country approach. ${ }^{29}$

To a certain extent, these changes reflected the growing awareness that the situation on the ground in transition economies was far more complex than the perfect state monopoly model on which the original non-market economy regime was based. However, the EU's move also had a political dimension, related to the efforts it had made since 1995 to enhance relations with China. ${ }^{30}$ It is no coincidence that the new regulation was passed little more than a month after the Commission had published a new policy document on relations with China and little more than three weeks after the first EU-China summit meeting had taken place in London. ${ }^{31}$ At the time, the European side was already well aware of the "great political significance" China attached to its status as a non-market economy, ${ }^{32}$ and the more favourable treatment of Chinese exporters was certainly intended as a friendly gesture towards China.

During the 1990s MES was also a big issue in China's WTO negotiations, but not in the bilateral ones with the EU. The provisions on China's status as non-market vs. market economy were a result of its negotiations with the US. ${ }^{33}$ The China-US Agreement of November 1999 established that for 15 years after accession the US would be allowed continue to treat China as a non-market economy and to apply its current practice with regard to anti-dumping procedures. ${ }^{34}$ Based on the mostfavoured-nation rule, these stipulations were then applied to China's relations with all other WTO members as well. ${ }^{35}$ As the EU's own anti-dumping rules were inspired by US practice, this also meant for the EU's treatment of China that nothing would have to change after China's accession to the WTO. Indeed, the Accession Protocol sets up a system that looks almost identical to the EU's approach as initiated in April 1998. The basic assumption is that market economy conditions do not prevail, with the burden to prove the contrary on Chinese producers. If they cannot demonstrate

28. Council Regulation (EC) No.905/98 of 27 April 1998, in: JO, L128, 30.04.1998; art.1, amending art 2(7) of Council Regulation (EC) No 384/96 of 22 December 1995, in: JO, L56, 06.03.1996.

29. Council Regulation (EC) No 2238/2000 of 9 October 2000, in: JO, L257, 11.10.2000 extended this hybrid regime to Kazakhstan, Ukraine, and Vietnam.

30. The first policy report exclusively devoted to relations with China was EUROPEAN COMMISSION, A Long-Term Policy for China-Europe Relations (COM(1995) 279 (final)).

31. See EUROPEAN COMMISSION, Building a Comprehensive Partnership with China (COM(1998) 181), as well as EU-China Summit: Joint Press Statement, 02.04.1998, Diplomacy (website), Chinese Embassy UK, last accessed on 05.10.2011, http://www.chinese-embassy.org.uk/eng/wjzc/ t27058.htm.

32. EUROPEAN COMMISSION, On the Treatment of Former Non-Market Economies in Anti-Dumping Proceedings (COM (1997) 677 final), p.5.

33. S. GREEN, op.cit., p.3, footnote 4.

34. See China-US Agreement on China's WTO Accession 1999, section “Anti-Dumping".

35. From a legal standpoint, for countries regarded as non-market economies WTO membership does not imply any change with regard to the anti-dumping regime (see B.V. HINDLEY, op.cit., p.54); the fact that for China a deadline has been put to non-market economy treatment should be interpreted as a success of Chinese negotiators, although they have been criticised at home for the long transition period. Interview China 4, Beijing Q2 2007. 
this, then "a methodology that is not based on a strict comparison with domestic prices or costs in China" can be applied. ${ }^{36}$

\section{Shifting Gear: China's Post-Accession Attempts}

Since China's accession to the WTO, there are two ways, according to the accession protocol, to achieve recognition as a market economy by other members. First, if China can show "under the national law of the importing WTO Member, that it is a market economy", or that a certain industry operates by market economy conditions, the special provisions of the accession protocol will end, for China as a whole or the industry in question, and the WTO's normal anti-dumping provisions will apply to bilateral commercial relations. Second, the accession protocol stipulates that the option of not using domestic prices or costs if the concerned producer fails to demonstrate that the business operates under market economy conditions will be terminated 15 years after accession, i.e. by late $2016 .{ }^{37}$ Generally this is interpreted as meaning that other WTO members will have to start treating China as a market economy. ${ }^{38}$

Towards the EU, China showed soon after becoming a WTO member that it was aiming at an early recognition of its MES based on the first option. The first public evidence of this was State Premier Zhu Rongji's invocation of the Chinese desire to be granted MES by the EU at the 5th EU-China summit in Denmark in September 2002. ${ }^{39} \mathrm{~A}$ few weeks later, Ms. Wu Yi, Chinese Vice-Premier in charge of international trade, called on the EU to grant China full MES during a visit to Beijing of Trade Commissioner Pascal Lamy. ${ }^{40}$ Then in June 2003, the Chinese Ministry of Commerce (MOFCOM) for the first time submitted a formal request to the Commission to be recognised as a market economy by the EU. ${ }^{41}$

36. WTO Decision of 10 November 2001 on Accession of the People's Republic of China, par. 15a(i) and 15 a(ii).

37. WTO Decision of 10 November 2001 on Accession of the People's Republic of China, par.15d.

38. Strictly speaking, the provision is not very clear, as the paragraph that puts the burden of proof on Chinese producers will not be invalidated after 15 years. Although some WTO members, and also the EU, may be tempted to use this ambiguity to extend the current regime beyond 2016, the general rhetoric has been that China would enjoy full MES from 2016, and it would be very difficult to resist the resulting political pressure.

39. China to further enhance China-EU relations, in: Xinhua General News Service, 24.09.2002; S. SUN, Zhu: Nation values China-EU dialogue, in: China Daily, 26.09.2002. MES did not make it into the official press communiqué at the end of the summit though; see Joint Press Statement of the Fifth EU-China Summit, 24.09.2002.

40. China calls on EU to grant it full market economy status, in: Xinhua General News Service, 17.10.2002; China urges EU to grant it full market economy status, in: Asia Pulse, 18.10.2002.

41. S. GREEN, op.cit., p.2; The receipt of a formal request at that time is also acknowledged in: EUROPEAN COMMISSION, A Maturing Partnership-Shared Interests and Challenges in EU-China Relations, (COM(2003) 533 fin.), p.19; Interview EU 29, Brussels Q1 2008. 
These initial approaches towards EU authorities, aimed at the Commission in particular, were very much in line with the logic of the EU's Common Commercial Policy where competence has been transferred to the EU level almost entirely. However, at the end of 2003 China shifted gears and lifted the MES issue from the channels of commercial diplomacy to the very top of its agenda for relations with the EU. Accordingly, it started exerting more pressure on the EU, and on a wider range of EU actors. Interestingly, this included also the member states although on most commercial issues their only formal influence is limited to participation in qualified majority voting in the Council. The first public indication that the Chinese approach was changing appeared during a visit of German Chancellor Gerhard Schröder to Beijing in December 2003. On this occasion Chinese Premier Mr. Wen Jiabao expressed his hope that Germany would exert a positive influence in bringing the EU to grant China MES. ${ }^{42}$ In March 2004, Chinese Minister of Commerce, Bo Xilai, emphasised China's desire to be recognised as a market economy towards Trade Commissioner Lamy and Irish Deputy Prime Minister and Minister of Enterprise, Trade and Employment, Mary Harney, also representing the Irish EU presidency. ${ }^{43}$ The same month, during a visit of Italian Vice-Minister for Productive Activities, Adolfo Urso to Beijing, Bo stated himself that Italy would push for the EU to grant China MES. ${ }^{44}$

The climax of this pattern of pressure on virtually any EU representative at hand, whatever the institutional affiliation, was Chinese Premier Mr. Wen Jiabao's 11-day visit to Europe in May 2004 which brought him to Germany, Belgium (including both Belgian government and EU institutions), Italy, UK and Ireland. During the meetings with top leaders, Wen called on his hosts to recognise China as a market economy. Chinese Vice-Premier Mr. Zeng Peiyan made a similar request in June 2004 during a visit to France. ${ }^{45}$

\section{EU Reactions to Chinese Pressure}

China's increasing pressure on the MES issue was just one aspect of a general upgrade of its relations with the EU, a late success of more than eight years of European efforts towards building stronger ties with China. The new emphasis on Europe became evident when the Chinese Ministry of Foreign Affairs reciprocated the Commission's fourth policy paper on China of September 2003 with the publication of China's EU

42. Chinese Premier, German Chancellor stress cooperation, in: BBC Monitoring Asia Pacific - Political, quoting Xinhua News Agency, 01.12.2003.

43. China will play active role in new WTO talks, in: Asia Pulse, 16.03.2004.

44. Sino-Italian [sic] to strengthen cooperation, in: Business Daily Update, 05.04.2004.

45. France, China discuss energy, transport, aviation cooperation, in: BBC Monitoring Asia-PacificPolitical, quoting Xinhua News Agency, 12.06.2004. 
Policy Paper a month later, the first document of this kind ever published by China. ${ }^{46}$ If previously the Chinese leadership had tended to neglect the European integration process, by 2004 the EU was "at the top of China's international agenda". ${ }^{47}$ Then at the 7th EU-China Summit in December 2004 the ambitious language of a "comprehensive strategic partnership" was used for the first time in a joint statement. ${ }^{48}$

As China turned towards the EU, two issues were at the core of its agenda: recognition of China's MES and the push for a lifting of the arms embargo that the EU had imposed on China in the aftermath of the violent repression of 1989. As China's top leaders, in particular Wen Jiabao, invested enormous political capital in the promotion of these issues, the pressure on the European side to give at least partial satisfaction to its new strategic partner was growing. From the perspective of the EU as whole, MES was clearly more suitable for concessions than the arms embargo. Firstly, the protectionist effect of anti-dumping is negligible when compared to the overall volume of EU-China trade, although it may concern politically influential industries. Secondly, recognition of MES would not have meant the end of anti-dumping action against China. Instead it would most likely have led to fewer and lower duties. Thirdly, while it could not be taken for granted that China would immediately return the favour, the EU would have put itself in a strong position to ask for Chinese concessions on trade issues in the future. Lastly, contrarily to the arms embargo issue, MES does not have any security implications that risk alienating other major partners, in particular the US.

Commission President Romano Prodi initially seemed to approach the issue from this angle. At the $6^{\text {th }}$ EU-China Summit in October 2003 in Beijing, he stated that he was "very optimistic about this" and that it was "something we will do within a short timeframe". ${ }^{49}$ This led to high expectations on the Chinese side. For example in March 2004 Chinese Minister of Commerce Bo Xilai asked for recognition of China's MES "as promised by President Prodi". ${ }^{50}$ In the first half of 2004, member states also repeatedly expressed their support for the Chinese request. In March Irish Deputy Prime Minister Mary Harney assured Minister of Commerce Bo that the Irish Council Presidency would promote the finding of a solution to the issue at an early date. ${ }^{51} \mathrm{In}$

46. MINISTRY OF FOREIGN AFFAIRS, China's EU Policy Paper, 13.10.2003. Aside from the Commission reports of 1995 and 1998 cited above (see footnotes 30 and 31), a third paper had been published in 2001; see EUROPEAN COMMISSION, EU Strategy towards China: Implementation of the 1998 Communication and Future Steps for a more Effective EU Policy, (COM(2001) 265 (final)).

47. L. XIANG, China's Eurasian Experiment, in: Survival, 2(2004), pp:109-122, here pp.112-113.

48. See COUNCIL OF THE EUROPEAN UNION, Joint Statement of the 7th EU-China Summit, 08.12.2004. On the significance of "strategic partnership" concept for China, see A. GOLDSTEIN, The Diplomatic Face of China 's Grand Strategy: A Rising Power's Emerging Choice, in: The China Quarterly, December 2001, pp,835-864, here: pp.855-856.

49. Prodi comments during press briefing at $6^{\text {th }}$ EU-China summit; see also Roundup: EU, China agree to address trade problems, seek economic partnership, in: AFX.com, 30.10.2003.

50. China will play active role in new WTO talks, in: Asia Pulse, 16.03.2004.

51. China willing to expand trade with Ireland, in: Business Daily Update, 19.03.2004. 
May State Premier Wen received assurance from all the five member states he visited that their governments backed China in its quest to receive MES from the EU, ${ }^{52}$ which led to a display of optimism on the Chinese side..$^{53}$

In stark contrast to these positive statements on the European side, at the end of June 2004 the Commission decided not to recognise China as a market economy, because it did not fulfil the EU's official criteria for market economies, as they had been established by the Council Regulation of April 1998. ${ }^{54}$ The conclusion was that despite "significant progress", further reforms in the financial sector and with regard to corporate and banking law, state interference and property law were necessary for a favourable decision on Chinese MES in the future. ${ }^{55}$ This reflected a different, more cautious line on MES that had been emerging slowly in the same months between 2003 and 2004. Already in October 2003, Trade Commissioner Lamy, unlike his boss Prodi, avoided any commitments, when he commented, in the context of the $19^{\text {th }}$ meeting of the Joint Committee of Economy and Trade in Beijing, that the Commission was working on the issue and would decide no later than the first half of $2004 .{ }^{56}$ By the time of Wen's visit to Europe in May 2004, Prodi had adopted the same approach and simply promised a decision by June 2004. ${ }^{57}$

After the Commission's first refusal China continued for some time to press for MES at the highest level and EU member states continued their positive stance on the issue. For instance, at the Asia-Europe Meeting in Hanoi in October 2004, Mi-

52. Chinese premier, German chancellor address Berlin high technology forum, in: BBC Monitoring Asia Pacific - Political, quoting from Xinhua News Agency, 04.05.2004; Chinese premier urges rewards from EU on economy, arms ban, in: Channel NewsAsia, 06.05.2004; Chinese premier Wen Jiabao raises proposal for promoting ties with Belgium, in: BBC Monitoring Asia Pacific - Political, quoting Xinhua News Agency, 06.05.2004; China, Britain agree to strengthen bilateral relations, in: BBC Monitoring Asia Pacific - Political, quoting Xinhua News Agency, 10.05.2004; Wen urges Europe to recognise China as market economy, in: Channel NewsAsia, 11.05.2004; Premier pushes for stronger Sino-Irish partnership, in: China Daily, 13.05.2004.

53. China Premier Wen confident of end to EU's arm ban, in: AFX.com, 06.05.2004; Wen's visit advances Sino-EU relations, in: China Daily, 14.05.2004; Chinese foreign minister views achievements of premier's European trip, in: BBC Monitoring Asia Pacific - Political, quoting Xinhua News Agency, 14.05.2004.

54. Council Regulation (EC) No.905/98 of 27 April 1998 (JO, L128, 30.4.1998) established the following criteria for a market economy (which have remained unchanged until the present): Decisions of firms on prices, costs and inputs must be based on the market signals of supply and demand; Firms must have one set of basic accounting records which are independently audited in line with international standards; Firms' production costs and financial situation must not be subject to distortions carried over from a former non-market economy system; Firms must be subject to bankruptcy and property laws that guarantee legal certainty and stability of their operation; Exchange rate conversions must be carried out at the market rate.

55. EU refuses to recognize China as 'market economy, in: Associated Press Worldstream, 28.06.2004; HONG KONG TRADE DEVELOPMENT COUNCIL, EU Still Refusing Market Economy Status for Mainland China, in: General and Market Reports, Issue 20, 29 September 2006.

56. China, EU to establish trade dialogue mechanism, in: BBC Monitoring Asia Pacific - Political, quoting Xinhua News Agency, 30.10.2003.

57. EU/China: Customs deal but no move in arms row during premier's visit, in: European Report, 08.05.2004. 
nister of Commerce Bo repeated the call on the EU to grant China MES, and, on the same occasion, assured a supportive statement by a French trade official. ${ }^{58}$ Similarly, at the 7th EU-China Summit in The Hague in December 2004, Premier Wen Jiabao raised the issue and received supportive statements from Dutch Prime Minister Jan Peter Balkenende both in his role as Council President and as Dutch head of government. ${ }^{59}$ However, in the following year an almost "ritualistic" practice emerged during meetings between EU member states and China: while the Chinese side called for MES, the European states expressed support but pointed out at the same time that this was an EU matter and that a single member cannot do much about it. ${ }^{60}$ This was the case, for example, in January 2005, both during the visit of Portuguese President Jorge Sampaio to Beijing, and when the head of the International Department of the Chinese Communist Party visited Italy. ${ }^{61}$ At the same time, Commission officials, like Deputy Head of EC Delegation in Beijing, Franz Jessen, or Peter Mandelson, new Trade Commissioner, tended to put more and more emphasis on the technical nature of the issue. ${ }^{62}$

This practice has remained largely unchanged until the latest, more emphatic, comments by Wen Jiabao. Other issues, like for example textile trade in 2005, moved to the top of the China-EU agenda, pushing MES to a less prominent space. Nevertheless the Commission's constant evaluation of China's performance in light of the EU's market economy criteria continued and the conclusions continued to be negative. In September 2006, Commission President José Manuel Barroso pointed out that the EU expected improvements with regard to state influence, accounting rules, bankruptcy laws, and financial services. ${ }^{63}$ Another formal review in 2008 adopted very positive language on numerous Chinese achievements but concluded again that the criteria were not yet fulfilled. ${ }^{64}$

58. Chinese, French trade official discuss fabric trade, IPR, in: Business Daily Update, 11.10.2004.

59. EU moves to lift arms embargo, in: China Daily, 09.12.2004; Chinese PM holds talks with Dutch counterpart, in: BBC Monitoring Asia Pacific - Political, quoting from Xinhua News Agency, 09.12.2004.

60. Interview EU 2 Berlin, Q1 2007; Interview EU 20 Beijing, Q3 2007.

61. China, Portugal issue joint communiqué on EU, human rights, in: BBC Monitoring Asia PacificPolitical, quoting from Xinhua News Agency, 13.01.2005; Italy pledges to push for early lifting of EU weapons export ban on China, in: BBC Monitoring International Reports, quoting from Xinhua News Agency, 21.01.2005.

62. See for example China exports to the EU jump 38\%, January to October, in: Asia Pulse, 15.12.2004, or A. CHANDA (World Markets Research Centre), EU trade commissioner discusses Chinese progress on market economy, human rights and IP protection, in: World Markets Analysis, 24.02.2005.

63. Brussels refuses to yield over market economy status for China, in: Financial Times, 11.09.2006.

64. EUROPEAN COMMISSION, Commission Staff Working Document on Progress by the People's Republic of China towards Graduation to Market Economy Status in Trade Defence Investigations, 9 September 2008, SEC(2008) 2503 final. 


\section{Explaining the European Refusal to Grant Market Economy Status}

Why did the EU choose not to make any concession on MES while at the same time not lifting the arms embargo, China's other main request? A first response to this question is that member states were divided on the issue. Many of the north-western member states wanted to be accommodating towards China on this issue. By contrast, a large group of mostly southern and eastern member states opposed granting MES, as they considered their industrial bases too vulnerable to Chinese competition and would not let go of a tool that could facilitate protective measures. ${ }^{65}$ As a result there was no qualified majority that would have supported recognition of China's MES.

To have member states divided on a specific policy issue is not unusual, especially when economic interests are involved. Oftentimes the Commission can act as a double negotiator in a two-level game, constructing an agreement that is acceptable both externally (to the international partner) and internally (to a qualified majority of member states), like for example in the final phase of the Uruguay Round. ${ }^{66}$ However, in the case of MES, the Commission did not manage to overcome the divisions, although the stakes were far smaller than in the Uruguay Round negotiations. The reason behind this inability to promote the general interest of the EU against national egoisms is related to the policy-making rules of the Common Commercial Policy.

Within the EU's Common Commercial Policy, two types of policies can be distinguished. ${ }^{67}$ First, there are those concerning the rules for imports into the EU. Here the Commission has the sole right of initiative and the Council accepts at qualified majority. Second, there are the rules concerning international negotiations. In this case, the Commission must first draft a negotiating mandate and have it approved by the Council at qualified majority. ${ }^{68}$ Then, and only then, can it negotiate an agreement. During the negotiations there is a constant exchange with a committee of member state representatives, which allows the Commission to play effectively the role of double negotiator.

Rules on anti-dumping, including the question of MES, fall under the first category of rules. This means the Commission's action is constrained by existing EU legislation, in particular Council Regulation (EC) No.905/98 of 27 April 1998 and

65. Interview EU 2, Berlin Q1 2007; Interview EU 26, Beijing Q4 2007; Interview EU 27, London Q1 2008; see also J. FOX, F. GODEMENT, op.cit., pp.26-27.

66. R.D. PUTNAM, Diplomacy and Domestic Politics: The Logic of Two-Level Games, in: International Organization, 3(1988).

67. See S. MEUNIER, K. NICOLAIDIS, The European Union as a Trade Power, in: C. HILL, M. SMITH (ed.), International Relations and the European Union, Oxford University Press, Oxford, 2011, pp.275-298.

68. This has changed with the entry into force of the Treaty of Lisbon, in that since then the ordinary legislative procedure applies to the Common Commercial Policy. This means that not only the Council but also the European Parliament has to accept Commission proposals. These are recent changes, however, which are not relevant for the period under review here. 
its provisions on the evaluation of technical criteria. ${ }^{69}$ As a result the Commission can only play a role of purely technical verification.

This limited scope of action stands in stark contrast to the political ambitions and sensitivities the Commission displayed in the context of MES. As visible in Commission President Prodi's statements in autumn 2003, there was initially a strong political will to grant MES as a foreign policy gesture. In 2005, Lamy's successor, Trade Commissioner Peter Mandelson expressed his awareness about the political dimension of the issue to a Chinese audience: "I know this is of great political importance for China. And I understand why. I am hearing you". ${ }^{70}$ That same year Serge Abou, head of the EU Delegation in Beijing, clearly indicated a desire to "sell" MES to China if it was ready to pay the right price: according to him the EU was ready to talk about MES but he added that "there is no free lunch". ${ }^{71}$ Commission President Barroso took a similar line in July 2005 when he said MES could not be granted anytime soon and any EU concession would have to be reciprocated by China. ${ }^{72}$

The only way out of this dilemma for the Commission would have been a mandate to negotiate on MES, and possibly related issues, with China. But a negotiating mandate was out of question given the adamant opposition to any concession by a number of member states, especially Italy. ${ }^{73}$ This meant that the Commission remained confined to a role of periodical verification of the technical criteria. The Commission's strategy to make the most out of its limited scope for action was to look almost desperately for Chinese concessions that would either be generous enough to convince the sceptics among the member states or that could be interpreted in some way as bringing China closer to the market economy criteria. ${ }^{74}$ However, the Commission's leeway was further reduced, as it came under strong pressure from the more protectionist member states not to engage in any "horse trading". ${ }^{75}$

The result of all this was a deadlock in Brussels that made any change of the status quo virtually impossible, not least because it created frustration and suspicion among the involved actors in Brussels. The consequence was that the only way China could theoretically gain MES before 2016 was by fulfilling entirely (or almost) the EU's technical criteria, an outcome that was judged as close to impossible by European officials. ${ }^{76}$ This forced fixation of Commission officials on the technical criteria constituted a strong mismatch with their Chinese counterparts who tended to emphasise

69. JO, L128, 30.04.1998.

70. A. CHANDA (World Markets Research Centre), EU trade commissioner discusses Chinese progress on market economy, human rights and IP protection, World Markets Analysis, 24.02.2005.

71. Europe 'ready to talk' on granting China market economy status - official, in: Xinhua Financial Network News, 13.06.2005; TSCHANG CHI-CHU, Market economy status next for China? Europe says it will repay China for its decision to restrict its textile exports, in: Straits Times, 14.06.2005.

72. EU's Barroso says time not right for China market economy status [sic], in: Xinhua Financial Network News, 14.07.2005.

73. Interview EU 2, Berlin Q1 2007; see also J. FOX, F. GODEMENT, op.cit, p.86.

74. Interview EU 29, Brussels Q1 2008.

75. Interview EU 32, Brussels Q1 2008.

76. Interview EU 20, Q3 2007; Interview EU 29, Brussels Q1 2008. 
more and more the status dimension of the issue, that China had a right to gain MES, and that it should not be required to make any concessions in exchange. ${ }^{77}$ Eventually the discussions with China on the issue also ended in deadlock, as illustrated by the fact that the common China-EU working group on MES only met once in November 2004 , and failed to bring any progress. ${ }^{78}$

\section{Conclusion}

This article has started out with an analysis of why China wants to be recognised as a market economy by the EU, focussing on commercial implications as well as on the question of status and prestige in international relations. It then traced Chinese initiatives towards the EU concerning MES as well as the EU reactions to them over the years following China's WTO membership. From the point of view of a common, forward-looking EU foreign policy, granting MES would have been an expedient decision. China had finally reacted positively to the EU's efforts of building stronger EU-China ties and was investing considerable political capital on two issues, MES and the arms embargo. Of the two, MES clearly had less controversial implications, especially considering the transatlantic alliance and the US commitment to Taiwanese security.

Nevertheless, MES has not been granted to China until today. To a large extent, the reason for the repeated negative reactions of the EU lies in the decision-making rules for the Common Commercial Policy. Based on existing legislation, the Commission was confined to assessing the technical market economy criteria of the Council Regulation of April 1998. As a result it could not play the role of a double negotiator, within the EU and with the outside partner, that brokers an acceptable compromise for all. The strong opposition of a few member states to any concession on MES had the consequence that the Commission had only minimal flexibility on the issue, not to mention a formal negotiating mandate.

From the point of view of EU foreign policy the outcome is far from satisfactory. Due to the contradictory statements, shifting from very positive to negative, the EU has created disappointment with an international partner whose company it had been seeking very actively since the mid-1990s, if not loss of face for some of the top officials with the most prominent public exposure on the issue. It has failed to create a more favourable context for interaction with China. Also, if it wanted to achieve anything in exchange for granting MES, be it directly or indirectly as a "sign of gratitude", the value of what it can expect to receive in exchange is constantly decreasing as we approach the 2016 deadline when China will receive MES anyway as stipulated in its WTO accession protocol.

77. Interview EU 20, Beijing Q3 2007; Interview EU 29, Brussels Q1 2008.

78. Interview EU 24, Beijing Q3 2007; Interview EU 29, Brussels Q1 2008. See also Nations hail SinoEuropean trade, in: Business Daily Update, 15.12.2004. 
The decision-making rules of the EU that led to a deadlock on the MES issue have been part of the EU's institutional structure since the Treaties of Rome. It is hard to imagine any feasible changes that would afford more freedom to the Commission, and hence more leeway to broker deals within and without the EU, so as to avoid a deadlock on strongly contested issues like MES. The latest changes resulting from Treaty of Lisbon may alter the game to a certain extent, not because the Council is no longer capable of blocking an issue, but rather because the involvement of the European Parliament may create a space of public debate in which it will be more difficult to take obstructive positions as in the case of MES. To get reliable conclusions on that, however, analysts will have to wait for an additional few years of practice under the Lisbon rules. 
